\title{
QE: Is There a Portfolio Balance Effect?
}

Daniel L. Thornton

The Federal Open Market Committee has recently attempted to stimulate economic growth using unconventional methods. Prominent among these is quantitative easing $(\mathrm{QE})$-the purchase of a large quantity of longer-term debt on the assumption that it will reduce long-term yields through the portfolio balance channel. Former Federal Reserve Chairman Ben Bernanke and others suggest that QE works through the portfolio balance channel, which implies a strong, statistically significant positive relationship between the public's holding of long-term Treasury debt and long-term Treasury yields. The author uses the econometric approach of Gagnon et al. (2011) and others to investigate the relationship between a variety of measures of the public's debt holding and various yield measures in the literature. The empirical results provide virtually no support for the portfolio balance channel. (JEL E52, E58, E43, E44)

Federal Reserve Bank of St. Louis Review, First Quarter 2014, 96(1), pp. 55-72.

All that quantitative easing (QE) does is to restructure the maturity of U.S. government debt in private hands. Now, of all the stories you've heard why unemployment is stubbornly high, how plausible is this: "The main problem is the maturity structure of debt. If only Treasury had issued $\$ 600$ billion more bills and not all these 5 year notes, unemployment wouldn't be so high. It's a good thing the Fed can undo this mistake."

Of course that's preposterous.

-John H. Cochrane, December 7, 2010

$\mathbf{T}$

he Federal Reserve aggressively increased the size of its balance sheet in the wake of Lehman Brothers' bankruptcy announcement on September 15, 2008. Coincident with the massive increase in the supply of reserves, the federal funds rate fell to nearly zero. ${ }^{1}$ With the funds rate at effectively zero, the Federal Open Market Committee (FOMC) turned to unconventional monetary policies. Prominent among these is the policy of large-scale asset purchases (LSAPs), referred to as quantitative easing (QE). The goal of QE is to stimulate investment and consumption by reducing longer-term yields (see, e.g., Woodford, 2001, 2012). Considerable research has been devoted to determining the impact of the Fed's QE

Daniel L. Thornton is vice president and presidential adviser at the Federal Reserve Bank of St. Louis. The author thanks Clemens Kool for helpful comments and Bryan Noeth, Sean Grover, and Li Li for valuable research assistance.

(c) 2014, The Federal Reserve Bank of St. Louis. The views expressed in this article are those of the author(s) and do not necessarily reflect the views of the Federal Reserve System, the Board of Governors, or the regional Federal Reserve Banks. Articles may be reprinted, reproduced, published, distributed, displayed, and transmitted in their entirety if copyright notice, author name(s), and full citation are included. Abstracts, synopses, and other derivative works may be made only with prior written permission of the Federal Reserve Bank of St. Louis. 
operations on long-term yields. This effort can be divided into two broad strands of the literature. The first is event studies that analyze high-frequency changes in bond yields following QE announcements (e.g., Gagnon et al., 2011; Krishnamurthy and Vissing-Jorgensen, 2011; Joyce et al., 2010; Neely, 2013; Swanson, 2011; Bauer and Rudebusch, 2011; Wright, 2012). ${ }^{2}$

The second strand of the literature uses lower-frequency (monthly) data to test the implication of the portfolio balance effect-namely, that there is a positive relationship between bond term premiums (and, consequently, bond yields) and the maturity structure of the public's holding of Treasury debt and long-term Treasury yields (e.g., Gagnon et al., 2011; Hamilton and $\mathrm{Wu}, 2012$; Krishnamurthy and Vissing-Jorgensen, 2012; Greenwood and Vayanos, forthcoming). This strand of the literature investigates the relationship between bond yields or term premiums and various measures of the public's holdings of Treasury debt prior to the FOMC's QE activities. Evidence of a statistically significant and economically important positive relationship prior to the FOMC's actions is used to infer how the FOMC's actions to reduce these supply measures should have affected term premiums or bond yields. This article contributes to this literature by investigating the relationship between long-term yields and the public's holding of long-term debt using a wide array of public debt and bond yield measures found in the literature. Following Gagnon et al. (2011) and Krishnamurthy and Vissing-Jorgensen (2012), I investigate the relationship within the context of a simple reduced-form framework that controls for a variety of macroeconomic and other variables. In implementing this methodology, I account for the trend in term premiums and bond yields over the sample period. To preview the empirical results, when the trend is accounted for, there is little evidence of a statistically significant effect of the Fed's LSAPs on yields and no evidence of an economically meaningful effect.

The article proceeds as follows. The next section briefly discusses the portfolio balance channel. I then review the previous empirical work in the literature and examine a variety of public debt, maturity/duration, and interest rate measures used in the literature. The next section presents the empirical results using these measures.

\section{THE PORTFOLIO BALANCE CHANNEL}

Many researchers and policymakers hypothesize that the Fed's LSAPs affect long-term yields through a variety of channels (see, e.g., Krishnamurthy and Jorgensen, 2011). However, many analysts (e.g., Bernanke, 2010, and Gagnon et al., 2011) have suggested that QE works through the portfolio balance channel. ${ }^{3}$ For example, Gagnon et al. $(2011$, p. 7$)$ say that QE reduces long-term yields because the Fed's LSAPs remove "a considerable amount of assets with high duration from the markets. With less duration risk to hold in the aggregate, the market should require a lower premium to hold that risk."

For the portfolio balance channel to be operative, the market for long-term debt must be effectively segmented from the rest of the financial market. Until recently, the idea that markets are segmented had gained relatively little traction among financial economists and policymakers. Skepticism that financial markets are segmented stems in part from the fact that yield differentials create arbitrage opportunities that the market will exploit. 
Consequently, it is not surprising that several analysts have expressed skepticism about the empirical significance of the portfolio balance channel. For example, Cochrane (2011, p. 16) suggests that the portfolio balance channel should be relatively weak because (i) "much of the Treasury bond supply is locked away in central bank and pension fund vaults" and "arbitrageurs take duration risk in mortgage-backed, corporate, and other markets" and (ii) the Fed's QE operations are "just a drop in the bucket." Bauer and Rudebusch $(2011$, p. 6) make a similar argument, noting that "the scale of the Fed's purchases of $\$ 1.725$ trillion of debt securities is small relative to the size of [domestic] bond portfolios" and "the global bond market-arguably, the relevant one-is several times larger." They conclude that the portfolio balance channel should be weak and suggest that the FOMC's LSAPs affect long-term yield through the signaling channel. Kocherlakota (2010) suggests that QE merely shifts interest rate risk from bondholders to taxpayers, and as a result "QE ends up having no effects, except for those associated with any new forward guidance that it signals."

\section{PREVIOUS LOW-FREQUENCY RESEARCH}

Hancock and Passmore (2011) and Stroebel and Taylor (2009) use lower-frequency monthly data to investigate the effect of the FOMC's purchases of mortgage-backed securities and find mixed results. Hancock and Passmore (2011) find a relatively large impact, while Stroebel and Taylor (2009) find a relatively small or statistically insignificant effect.

D'Amico and King (2010) and D'Amico et al. (2012) investigate the effects of QE on the Treasury yield curve using micro-transactions data. D'Amico and King (2010) estimate both flow and stock effects; the former are the response of prices to ongoing purchases and the latter are changes due to expectations about future withdrawals of supply. They find small and temporary flow effects. The stock effect based on a counterfactual yield curve from their model suggests that the nearly $\$ 300$ billion purchase of Treasury securities would flatten the yield curve in the range of 10 to 15 years by 45 basis points. However, when the observations on key QE announcements days are omitted, only one of the own response or cross-response coefficients is statistically significant. This fact would seem to suggest that their results are critically dependent on an announcement effect.

D’Amico et al. (2012) suggest that QE can affect long-term yields and term premiums through three channels. The first is called the scarcity channel, which they define as "a mechanism under which the purchase by the Federal Reserve of assets with a specific maturity leads to higher prices (and lower yields) of securities with similar maturities" (p. 2). The second is called the duration channel, defined as "a mechanism under which the removal... of aggregate duration from the outstanding stock of Treasury debt reduces term premiums on securities across maturities" (p. 2). The duration channel seems to be very similar to the portfolio balance channel. The third is the signaling channel. D'Amico et al. identify scarcity by creating maturity "buckets" consisting of the public's holdings of Treasury securities of given maturities relative to total Treasury debt outstanding. ${ }^{4}$ They find that both the scarcity and duration channels are statistically significant; however, the duration channel accounts for only a third or a fourth of their estimate of the total effect. They find no evidence of an important signaling channel. 
Greenwood and Vayanos (forthcoming) focus directly on the portfolio balance channel by organizing their empirical analysis based on Vayanos and Vilas (2009) segmented-markets model. Specifically, they estimate regressions of bond yields and excess returns on the ratio of maturity-weighted debt to gross domestic product (GDP). They find a positive relationship between their debt measure and both yields and returns, but the estimates are statistically significant only for returns on bonds with maturities of five years or longer.

Just as Greenwood and Vayanos (forthcoming) do, Gagnon et al. (2011) investigate the effect of QE on long-term yields using a measure of the public's holding of Treasury debt. Specifically, Gagnon et al. (2011) estimate the equation as follows:

$$
i_{t}=\alpha+X_{t} \beta+\delta p d_{t}+\varepsilon_{t}
$$

Gagnon et al. (2011) use two measures of $i$, the 10-year Treasury yield and an estimate of the 10 -year Treasury term premium. $X$ is a $[1 \times K]$ vector of macroeconomic variables and $p d$ is a measure of the public's holding of Treasury debt, where $\alpha, \beta$, and $\delta$ are constant coefficients, and $\varepsilon$ is a random error with a zero mean and a constant variance. They estimate the equation over the period January 1985 through June 2008. Their estimate of the supply effect suggests that the FOMC's $\$ 1.75$ trillion asset purchase $(\mathrm{QE} 1)$ should have reduced the term premium by about 52 basis points and the 10-year Treasury yield by about 82 basis points.

Hamilton and $\mathrm{Wu}$ (2012) investigate the effect of QE by estimating a three-factor affine term structure model, using assumptions motivated by Vayanos and Vila's (2009) model. Specifically, they calculate arbitrageurs' portfolio weights under the assumptions that arbitrageurs comprise the entire private sector and U.S. Treasury debt is held only by arbitrageurs. They use the estimates from their model to infer how changes in the maturity structure of Treasury debt can affect yields. Their estimates of the effect of QE1 on the 10-year Treasury yield and term spreads are smaller than those reported by Gagnon et al. (2011), Greenwood and Vayanos (forthcoming), and D'Amico and King (2010). The effect of QE2 was perverse: The Fed's asset purchase program increased Treasury yields and term premiums. Hamilton and $\mathrm{Wu}(2012$, p. 38) attribute this to the fact that the "fraction of publicly held debt of more than 10 years maturity continued to increase even as the Fed was implementing its QE2 bond purchases."

\section{THE RELATIONSHIP BETWEEN LONG-TERM YIELDS AND THE SUPPLY OF PUBLIC DEBT}

This section investigates the relationship between long-term yields and the supply of public debt using the methodology of Gagnon et al. (2011). The analysis differs from previous work in the literature in that I consider several debt supply measures used in the literature and alternative yield measures. The analysis begins with a discussion of the public debt measures used in the literature. 


\section{Figure 1}

\section{Public's Holding of Treasury Debt, Net of SOMA}

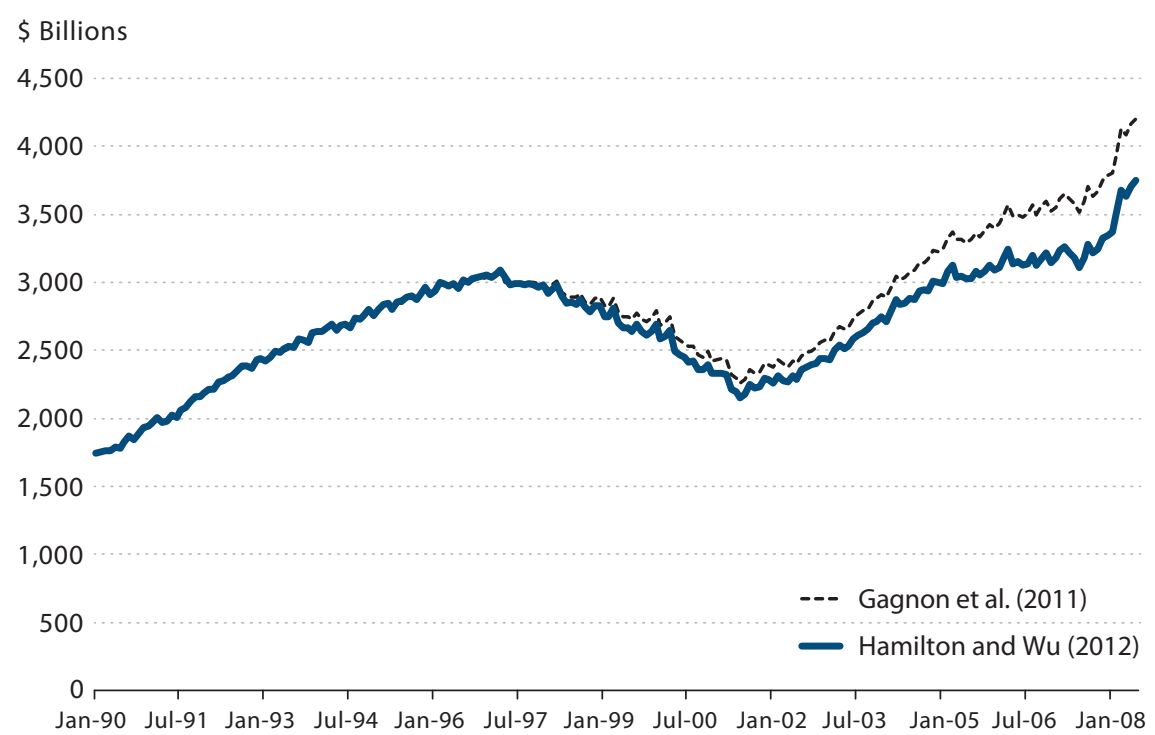

\section{Alternative Debt Supply Measures}

This section analyzes alternative debt measures used in the literature to investigate the portfolio balance channel. The debt measures are those used by Gagnon et al. (2011), Hamilton and $\mathrm{Wu}$ (2012), and Greenwood and Vayanos (forthcoming). ${ }^{5}$ Gagnon et al. (2011) and Hamilton and $\mathrm{Wu}$ (2012) use data on the public's holding of Treasury debt, less that held by the Fed in the System Open Market Account (SOMA). Figure 1 shows these series for the period January 1990 through June 2008. The series are nearly identical until the late 1990s when they begin to diverge. The difference is likely due to the inclusion of Treasury inflationprotected securities (TIPS) in Gagnon et al.s data. Hamilton and Wu's data do not include TIPS. ${ }^{6}$

Gagnon et al. (2011) consider only the public's holdings of government debt with maturities of one year or longer, net of SOMA. This series is shown in Figure 2. However, they make several adjustments to this series. First, they subtract foreign official holdings of Treasury securities with maturities of one year or longer because foreign governments are unlikely to have a term premium similar to that of the private sector. The resulting series (S2) is also shown in Figure 2.

Rather than using the $S 2$ series, Gagnon et al. (2011) also subtract foreign official holdings of agency and private sector debt with maturities of at least one year. This adjustment is inappropriate because agency and private securities are not included in S2. The resulting series (S3), also shown in Figure 2, is negative beginning in November 2007, when foreign official holdings of agency and private sector debt become larger than the public's holding of Treasury debt. ${ }^{7}$ As a final adjustment, Gagnon et al. (2011) express $S 3$ as a percent of nominal GDP ( $\left.S 3^{g d p}\right)$. 


\section{Thornton}

Figure 2

\section{Alternative Measure of the Public's Holding of Government Debt}

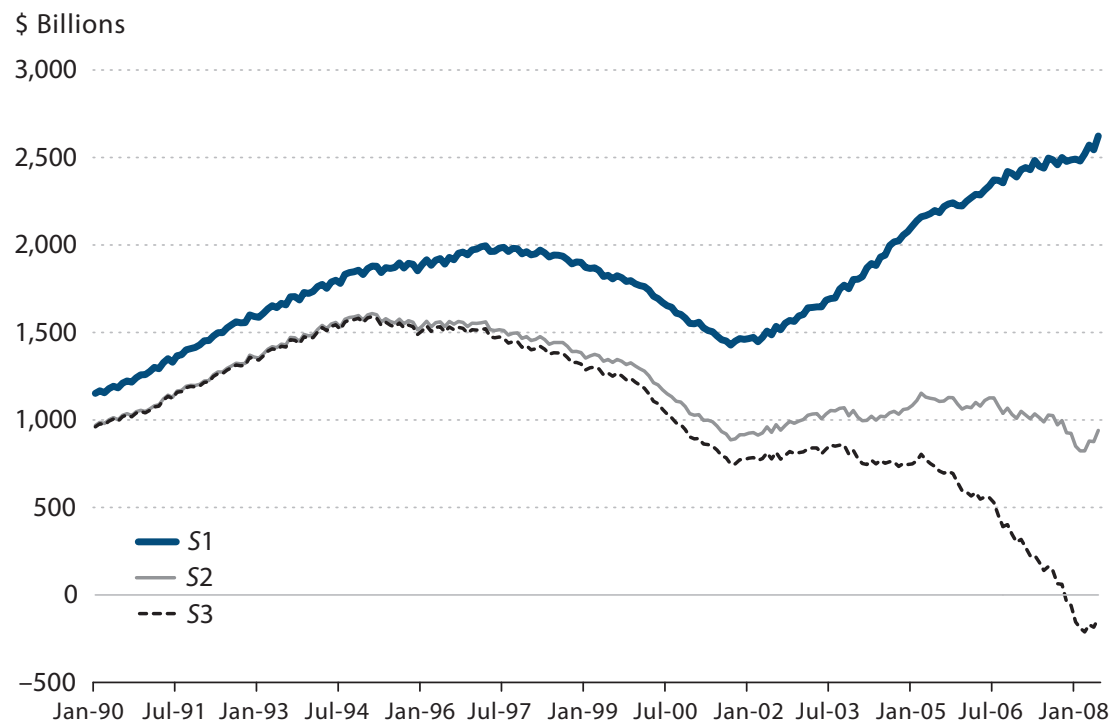

Figure 3

Gagnon et al. and Greenwood and Vayanos Supply Measures

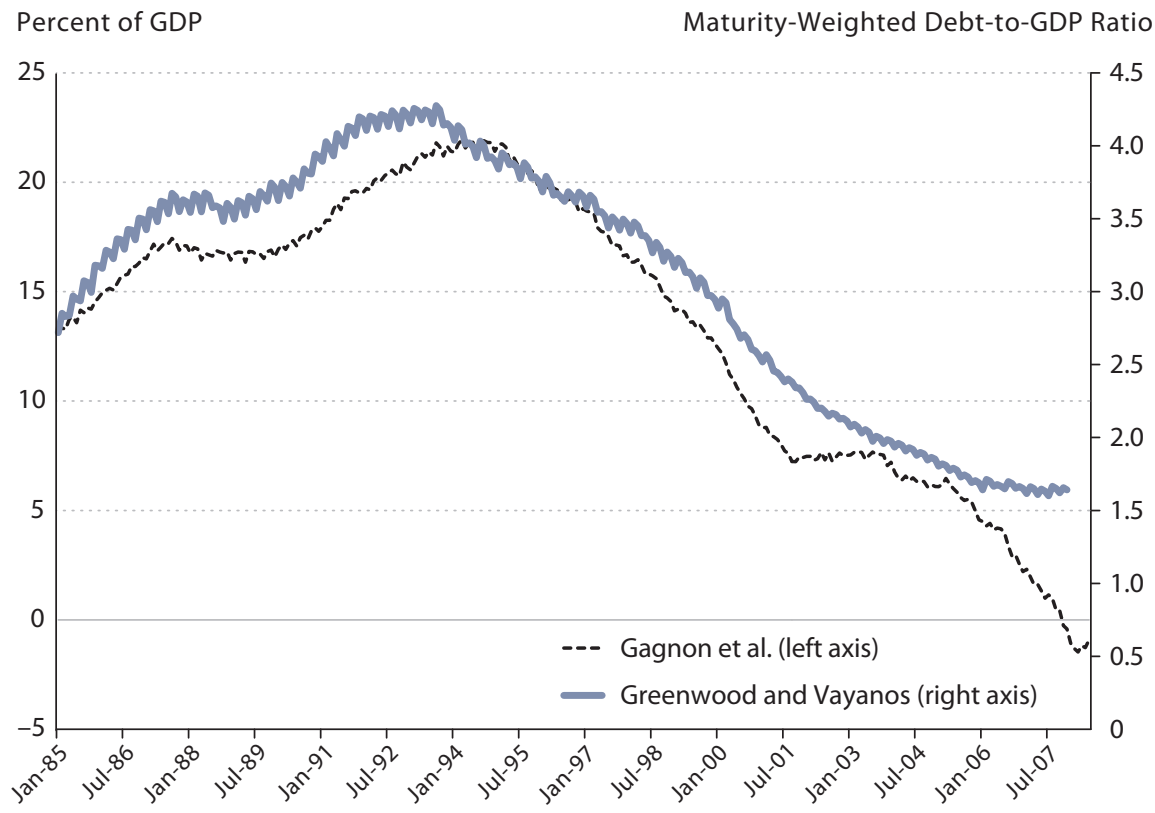




\section{Figure 4}

\section{Average Maturity and Percent of Debt Greater Than 10 Years to Maturity}

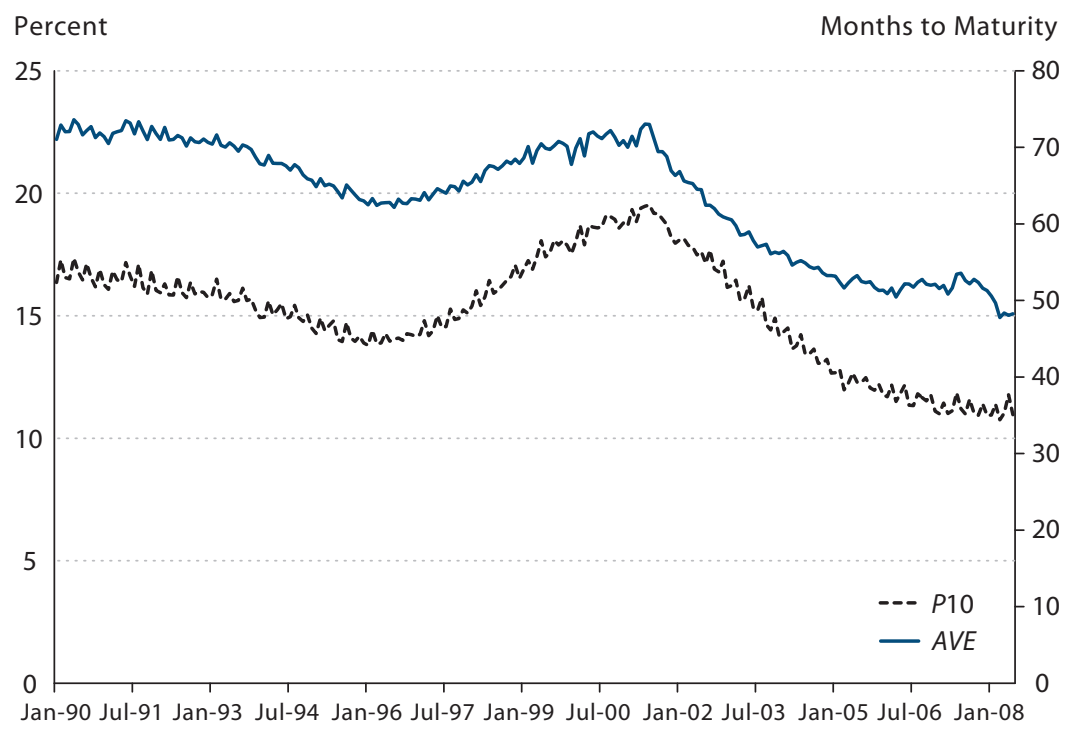

Greenwood and Vayanos (forthcoming) use data from the Center for Research in Securities Prices (CRSP) for every government bond issued between 1940 and 2007 without netting out Fed or agency holdings. Specifically, they construct the maturity structure of the debt by aggregating cash flows across individual bonds-that is, the sum of all principal and coupon payments due over the maturity of each bond issued. They then construct a maturity-weighted debt-to-GDP ratio supply measure. Figure 3 shows this measure with Gagnon et al's (2011) $S 3^{\text {gdp }}$ measure. ${ }^{8}$ While the two measures differ greatly in scale, they follow a very similar pattern: Both rise until the mid-1990s and then decline. Gagnon et al.s measure declines more dramatically because they subtract foreign official holdings of agency and private debt, while Greenwood and Vayanos's measure is based solely on the public's holdings of Treasury debt.

Hamilton and $\mathrm{Wu}$ (2012) do not use the debt measure shown in Figure 1 but rather the average maturity of public debt $(A V E)$ and the percent of public debt with maturities longer than 10 years $(P 10)$ (Figure 4$)$. The series behave similarly over the sample period; the correlation is 84 percent.

\section{The Data: Term Premiums and Treasury Yields}

This section considers alternative measures of interest rates used in the literature. Gagnon et al. (2011) evaluate the effectiveness of QE by estimating the effect of the Fed's purchase of securities on an estimate of the 10-year Treasury term premium (TP) and the zerocoupon 10-year Treasury bond yield (T10). ${ }^{9}$ Their estimate of TP is obtained from the term structure model of Kim and Wright (2005). Figure 5 shows strong negative trends and similar 
Figure 5

10-Year Treasury Yield and Term Premium

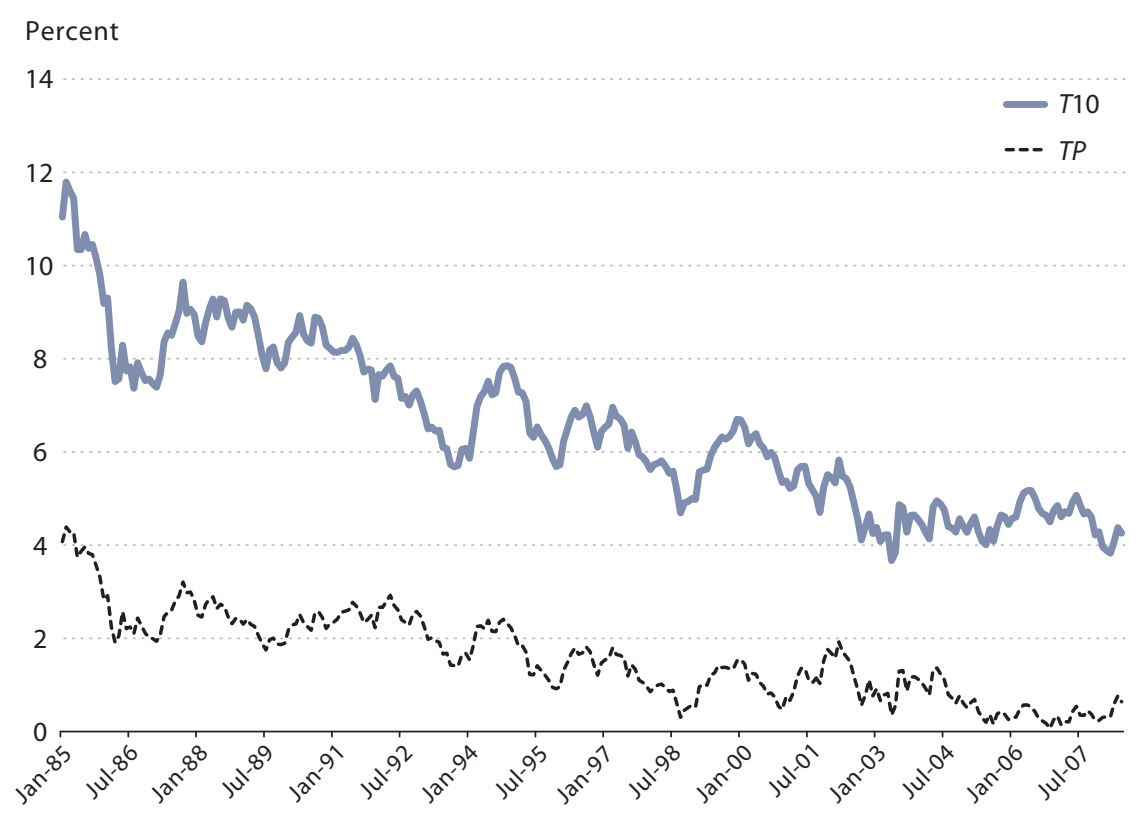

Figure 6

Public's Holding of Treasury Debt, Net of SOMA

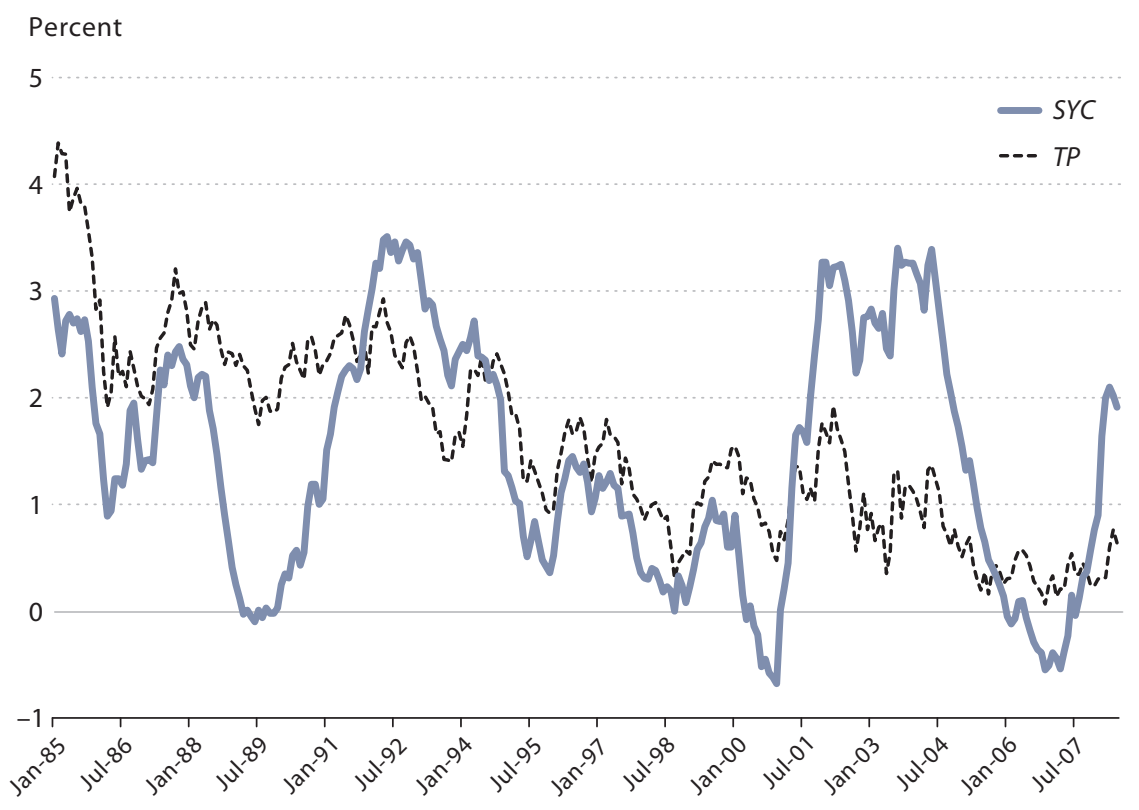




\section{Table 1}

\begin{tabular}{|c|c|c|c|c|c|c|c|c|c|c|}
\hline Variable & Coefficient & $p$-Value & Coefficient & $p$-Value & Coefficient & $p$-Value & Coefficient & $p$-Value & Coefficient & $p$-Value \\
\hline Const. & 0.203 & 0.775 & -3.277 & 0.000 & -2.730 & 0.000 & -2.182 & 0.000 & -2.503 & 0.000 \\
\hline gap & 0.241 & 0.000 & 0.220 & 0.000 & 0.211 & 0.000 & 0.180 & 0.002 & 0.192 & 0.001 \\
\hline cpi & 0.320 & 0.000 & 0.497 & 0.000 & 0.433 & 0.000 & 0.307 & 0.000 & 0.284 & 0.000 \\
\hline Irid & 0.250 & 0.015 & 0.374 & 0.001 & 0.381 & 0.000 & 0.377 & 0.001 & 0.378 & 0.001 \\
\hline$r v$ & 0.492 & 0.053 & 1.225 & 0.000 & 1.094 & 0.000 & 0.943 & 0.000 & 1.049 & 0.000 \\
\hline S1 & -0.001 & 0.003 & & & & & & & & \\
\hline$S 2$ & & & 0.001 & 0.000 & & & & & & \\
\hline S3 & & & & & 0.001 & 0.000 & & & & \\
\hline S3gdp & & & & & & & 0.044 & 0.000 & & \\
\hline$S^{G V}$ & & & & & & & & & 0.289 & 0.000 \\
\hline $\bar{R}^{2}$ & \multicolumn{2}{|c|}{0.812} & \multicolumn{2}{|c|}{0.816} & \multicolumn{2}{|c|}{0.842} & \multicolumn{2}{|c|}{0.847} & \multicolumn{2}{|c|}{0.843} \\
\hline SE & \multicolumn{2}{|c|}{0.402} & \multicolumn{2}{|c|}{0.398} & \multicolumn{2}{|c|}{0.365} & \multicolumn{2}{|c|}{0.363} & \multicolumn{2}{|c|}{0.362} \\
\hline
\end{tabular}

NOTE: SE, standard error.

cycles for $T 10$ and $T P$. The correlation between $T P$ and $T 10$ is very high, 94 percent. Given the similarity of these series, it is not surprising that the results are qualitatively similar with either measure.

Hamilton and $\mathrm{Wu}$ (2012) investigate the effectiveness of the portfolio balance channel using the slope of the yield curve (SYC), measured by the difference between the constant maturity 10-year Treasury zero coupon bond yield and the 6-month T-bill rate. Figure 6 shows SYC and TP over the period January 1985 through June 2008.

\section{The Effectiveness of the Portfolio Balance Channel}

This section reports the estimates of equation (1) using these alternative measures of $i_{t}$ (TP and SYC) and a variety of measures of $p d_{t}$. The macroeconomic variables are those used by Gagnon et al. (2011): the unemployment gap ( $g a p$ ), core consumer price index inflation (cpi), long-run inflation disagreement (lrid), and 6-month realized daily volatility of the onthe-run 10-year Treasury yield $(r v) .{ }^{10}$

Table 1 presents the estimates using $T P$ as the dependent variable and the alternative measures of the public's holding of Treasury debt discussed previously (see "Alternative Debt Supply Measures"). Contrary to the implication of the portfolio balance channel, the coefficient on the public's holding of debt net of SOMA, $S 1$, is negative and statistically significant. However, when foreign official holdings of Treasury debt are netted out, the estimate is positive and statistically significant. A coefficient of the same magnitude and statistical significance is obtained when foreign official holdings of agency and private debt are netted out. Hence, despite the abnormal nature of this adjustment, it has no effect on the results: A $\$ 600$ billion LSAP would reduce the term premium by 40 basis points. 


\section{Thornton}

\section{Table 2}

Estimates of Equation (1) Accounting for the Trend (January 1985-June 2008)

\begin{tabular}{|c|c|c|c|c|c|c|c|c|c|c|}
\hline Variable & Coefficient & $p$-Value & Coefficient & $p$-Value & Coefficient & $p$-Value & Coefficient & $p$-Value & Coefficient & $p$-Value \\
\hline Const. & 1.035 & 0.058 & 0.164 & 0.850 & -0.380 & 0.671 & -0.071 & 0.945 & -0.399 & 0.715 \\
\hline gap & 0.205 & 0.000 & 0.200 & 0.000 & 0.201 & 0.000 & 0.192 & 0.001 & 0.196 & 0.001 \\
\hline cpi & 0.109 & 0.097 & 0.156 & 0.054 & 0.207 & 0.024 & 0.158 & 0.056 & 0.167 & 0.032 \\
\hline Irid & 0.244 & 0.029 & 0.276 & 0.020 & 0.301 & 0.009 & 0.292 & 0.016 & 0.297 & 0.013 \\
\hline$r v$ & 0.394 & 0.056 & 0.574 & 0.005 & 0.665 & 0.001 & 0.590 & 0.003 & 0.681 & 0.002 \\
\hline Trend & -0.006 & 0.000 & -0.006 & 0.000 & -0.004 & 0.010 & -0.005 & 0.053 & -0.004 & 0.069 \\
\hline$S 1$ & -0.0001 & 0.533 & & & & & & & & \\
\hline$S 2$ & & & 0.0002 & 0.409 & & & & & & \\
\hline S3 & & & & & 0.0003 & 0.145 & & & & \\
\hline S3gdp & & & & & & & 0.0160 & 0.368 & & \\
\hline$S G V$ & & & & & & & & & 0.1150 & 0.363 \\
\hline $\bar{R}^{2}$ & \multicolumn{2}{|c|}{0.855} & \multicolumn{2}{|c|}{0.856} & \multicolumn{2}{|c|}{0.856} & \multicolumn{2}{|c|}{0.857} & \multicolumn{2}{|c|}{0.851} \\
\hline SE & \multicolumn{2}{|c|}{0.353} & \multicolumn{2}{|c|}{0.352} & \multicolumn{2}{|c|}{0.348} & \multicolumn{2}{|c|}{0.352} & \multicolumn{2}{|c|}{0.353} \\
\hline
\end{tabular}

NOTE: SE, standard error.

The estimates using $S 3^{g d p}$ are, of course, identical to those of Gagnon et al. (2011). While the coefficient on $S 3^{\text {gdp }}$ is larger than that on $S 3$, the estimated magnitude of the effect of LSAPs is smaller. A $\$ 600$ billion LSAP is about 4.0 percent of 2009 GDP, so the estimated effect of the same $\$ 600$ billion LSAP would be half as large, about 19 basis points. Given the similarity between $S 3^{\text {gdp }}$ and $S^{G V}$, it is not surprising that the estimate of the coefficient also is positive and highly statistically significant when Greenwood and Vayanos's (forthcoming) measure is used.

Unfortunately, the results in Table 1 are the consequence of trends in TP and public debt measures. A simple linear trend accounts for nearly 80 percent of the variation in $T P$ and a small but still relatively large (as much as 60 percent) portion of the variation in the supply measures. The existence of trends can lead to spurious regression in that two variables that trend in the same direction will be positively correlated even if they are independent of each other. The importance of the trend in these measures is shown in Table 2, which reports the estimates of equation (1) when a simple linear trend is included in the equation. The coefficient on $S 1$ remains negative but is not statistically significant. The coefficients on the other debt measures remain positive but much smaller than the estimates in Table 1; more importantly, none is statistically significant at even the 10 percent significance level. When the trend is accounted for, the statistical support for the portfolio balance channel vanishes. This conclusion is the same if the trend is obtained using the Hodrick-Prescott filter or if the equation is estimated in first differences. Hence, there is no statistically significant positive relationship between the term premium and any of the debt measures considered here (i.e., no statistical support for the portfolio balance channel) when the trend is accounted for. 


\section{Table 3}

\section{Estimates of Equation (1) Using Alternative Supply Measures and Accounting for the Trend (January 1985-June 2008)}

\begin{tabular}{|c|c|c|c|c|c|c|c|c|c|c|}
\hline Variable & Coefficient & $p$-Value & Coefficient & $p$-Value & Coefficient & $p$-Value & Coefficient & $p$-Value & Coefficient & $p$-Value \\
\hline Const. & 0.0831 & 0.9198 & 0.6770 & 0.2145 & 2.4388 & 0.0092 & 9.0658 & 0.0000 & -0.0500 & 0.9602 \\
\hline gap & 0.2169 & 0.0002 & 0.2068 & 0.0003 & 0.2055 & 0.0002 & 0.3410 & 0.0000 & 0.2028 & 0.0002 \\
\hline сpi & 0.1874 & 0.0006 & 0.1882 & 0.0006 & 0.0923 & 0.2075 & 0.0227 & 0.6266 & 0.1670 & 0.0399 \\
\hline Irid & -0.0577 & 0.4817 & -0.0611 & 0.4622 & 0.1729 & 0.0904 & 0.0821 & 0.1560 & 0.2898 & 0.0143 \\
\hline$r v$ & 0.6981 & 0.0007 & 0.6682 & 0.0012 & 0.4253 & 0.0507 & 0.5823 & 0.0000 & 0.6110 & 0.0027 \\
\hline Trend & -0.0060 & 0.0000 & -0.0069 & 0.0000 & -0.0061 & 0.0000 & 0.0002 & 0.7840 & -0.0055 & 0.0001 \\
\hline$A M$ & 0.0130 & 0.1439 & & & & & & & & \\
\hline$P 10$ & & & 0.0246 & 0.2020 & & & & & & \\
\hline$D U R$ & & & & & -0.2569 & 0.0497 & & & & \\
\hline DUR10 & & & & & & & -1.1908 & 0.0000 & & \\
\hline S2duradj & & & & & & & & & 0.0003 & 0.2970 \\
\hline $\bar{R}^{2}$ & \multicolumn{2}{|c|}{0.8366} & \multicolumn{2}{|c|}{0.8357} & \multicolumn{2}{|c|}{0.8588} & \multicolumn{2}{|c|}{0.9227} & \multicolumn{2}{|c|}{0.8540} \\
\hline SE & \multicolumn{2}{|c|}{0.2995} & \multicolumn{2}{|c|}{0.3003} & \multicolumn{2}{|c|}{0.3452} & \multicolumn{2}{|c|}{0.2555} & \multicolumn{2}{|c|}{0.3511} \\
\hline
\end{tabular}

NOTE: SE, standard error.

Table 3 presents the estimates using five alternative supply measures: the average maturity of the debt $(A M)$, the percent of the public's holding of debt with maturity of 10 years or longer $(P 10)$, the duration of the public's holding of the debt (DUR), the duration of the on-the-run 10-year Treasury securities (DUR10), and the $S 2$ debt measure adjusted for the duration of the debt using Gagnon et al.s (2011) adjustment procedure ( $S 2^{\text {duradj }}$ ). $A M$ and $P 10$ are calculated from Hamilton and Wu's (2012) data, which cover the period January 1990 through June 2008. Hence, this is the sample period when these variables are used. DUR and DUR10 data were provided by Gagnon et al. (2011).

The coefficients on $A M$ and $P 10$ are positive, but neither is statistically significant. The estimates for the two duration measures are negative and statistically significant, suggesting that a shortening of the duration of the public's holding of government debt as the result of LSAPs would increase the term premium. The coefficient on $S 2^{\text {duradj }}$ is positive but not statistically significant. Hence, these alternative measures also provide no support for the portfolio balance channel. ${ }^{11}$ Again, the conclusion is robust to the measure of trend used, whether the equation is estimated using first differences or whether T10 is the dependent variable (Tables 4 and 5).

The portfolio balance channel is thought to reduce longer-term rates relative to shorterterm rates, so equation (1) is estimated using SYC as the dependent variable and all 10 supply measures. Unlike TP and T10, there is no significant trend in SYC. However, SYC is highly persistent, so $S Y C_{t-1}$ is included in the regression. 


\section{Thornton}

\section{Table 4}

\section{Estimates of Equation (1) Using Dependent Variable T10 and Not Accounting for the Trend (January 1985-June 2008)}

\begin{tabular}{|c|c|c|c|c|c|c|c|c|}
\hline Variable & Coefficient & $p$-Value & Coefficient & $p$-Value & Coefficient & $p$-Value & Coefficient & $p$-Value \\
\hline Const. & 4.8405 & 0.0000 & 4.0288 & 0.0018 & 4.3217 & 0.0036 & 4.4339 & 0.0059 \\
\hline gap & -0.2472 & 0.0037 & -0.2529 & 0.0035 & -0.2477 & 0.0036 & -0.2576 & 0.0048 \\
\hline cpi & 0.3100 & 0.0044 & 0.3770 & 0.0029 & 0.3734 & 0.0100 & 0.3389 & 0.0092 \\
\hline Irid & 0.6654 & 0.0003 & 0.7113 & 0.0001 & 0.7003 & 0.0001 & 0.7002 & 0.0001 \\
\hline$r v$ & 0.2827 & 0.4145 & 0.4109 & 0.2282 & 0.3425 & 0.3308 & 0.3032 & 0.3738 \\
\hline Trend & -0.0146 & 0.0000 & -0.0123 & 0.0000 & -0.0119 & 0.0000 & -0.0117 & 0.0016 \\
\hline$S 1$ & 0.0003 & 0.3116 & & & & & & \\
\hline$S 2$ & & & 0.0004 & 0.2610 & & & & \\
\hline S3 & & & & & 0.0002 & 0.4527 & & \\
\hline S3gdp & & & & & & & 0.0165 & 0.5699 \\
\hline $\bar{R}^{2}$ & \multicolumn{2}{|c|}{0.8999} & \multicolumn{2}{|c|}{0.9007} & \multicolumn{2}{|c|}{0.8998} & \multicolumn{2}{|c|}{0.8995} \\
\hline SE & \multicolumn{2}{|c|}{0.5536} & \multicolumn{2}{|c|}{0.5513} & \multicolumn{2}{|c|}{0.5539} & \multicolumn{2}{|c|}{0.5548} \\
\hline
\end{tabular}

NOTE: SE, standard error.

\section{Table 5}

Estimates of Equation (1) Using Dependent Variable T10 and Accounting for the Trend (January 1985-June 2008)

\begin{tabular}{|c|c|c|c|c|c|c|c|c|c|c|}
\hline Variable & Coefficient & $p$-Value & Coefficient & $p$-Value & Coefficient & $p$-Value & Coefficient & $p$-Value & Coefficient & $p$-Value \\
\hline Const. & 6.6212 & 0.0000 & 6.1643 & 0.0000 & 11.0086 & 0.0000 & 19.8398 & 0.0000 & 4.4411 & 0.0012 \\
\hline gap & -0.2560 & 0.0021 & -0.2567 & 0.0021 & -0.2396 & 0.0039 & -0.0044 & 0.9117 & -0.2462 & 0.0035 \\
\hline cpi & 0.3168 & 0.0034 & 0.3003 & 0.0045 & 0.2136 & 0.0402 & 0.1312 & 0.0259 & 0.3490 & 0.0052 \\
\hline Irid & 0.5869 & 0.0009 & 0.5998 & 0.0009 & 0.3925 & 0.0088 & 0.3632 & 0.0000 & 0.6992 & 0.0001 \\
\hline$r v$ & 0.0956 & 0.7541 & 0.1266 & 0.6949 & 0.0761 & 0.8035 & 0.3908 & 0.0098 & 0.3286 & 0.3340 \\
\hline Trend & -0.0143 & 0.0000 & -0.0139 & 0.0000 & -0.0125 & 0.0000 & -0.0019 & 0.0741 & -0.0126 & 0.0000 \\
\hline$A M$ & -0.0146 & 0.4315 & & & & & & & & \\
\hline$P 10$ & & & -0.0364 & 0.3105 & & & & & & \\
\hline DUR & & & & & -0.8946 & 0.0000 & & & & \\
\hline DUR10 & & & & & & & -2.0904 & 0.0000 & & \\
\hline S2duradj & & & & & & & & & 0.0004 & 0.4904 \\
\hline $\bar{R}^{2}$ & & 8999 & & 9001 & & .9238 & & 9594 & & .8996 \\
\hline SE & & 5537 & & 5532 & & .4831 & & 3527 & & .5544 \\
\hline
\end{tabular}

NOTE: SE, standard error. 


\section{Table 6}

Estimates of Equation (1) with SYC as Dependent Variable (January 1985-June 2008)

\begin{tabular}{|c|c|c|c|c|c|c|c|c|c|c|}
\hline Variable & Coefficient & $p$-Value & Coefficient & $p$-Value & Coefficient & $p$-Value & Coefficient & $p$-Value & Coefficient & $p$-Value \\
\hline Const. & 0.0568 & 0.8479 & 0.2655 & 0.1046 & 0.1996 & 0.0456 & 0.1632 & 0.0646 & 0.1640 & 0.1060 \\
\hline gap & 0.1086 & 0.0071 & 0.1135 & 0.0050 & 0.1088 & 0.0053 & 0.1137 & 0.0034 & 0.1108 & 0.0038 \\
\hline cpi & 0.0338 & 0.2599 & 0.0264 & 0.1451 & 0.0326 & 0.0637 & 0.0486 & 0.0148 & 0.0422 & 0.0528 \\
\hline Irid & -0.1099 & 0.0001 & -0.1194 & 0.0001 & -0.1189 & 0.0000 & -0.1212 & 0.0000 & -0.1160 & 0.0001 \\
\hline$r v$ & 0.2528 & 0.0013 & 0.2125 & 0.0037 & 0.2214 & 0.0027 & 0.2343 & 0.0015 & 0.2164 & 0.0026 \\
\hline$S Y C_{t-1}$ & 0.9085 & 0.0000 & 0.9066 & 0.0000 & 0.9112 & 0.0000 & 0.9112 & 0.0000 & 0.9119 & 0.0000 \\
\hline S1 & 0.0000 & 0.8088 & & & & & & & & \\
\hline S2 & & & -0.0001 & 0.3315 & & & & & & \\
\hline S3 & & & & & 0.0000 & 0.1937 & & & & \\
\hline S3gdp & & & & & & & -0.0051 & 0.0795 & & \\
\hline$S_{G V}$ & & & & & & & & & -0.0170 & 0.4623 \\
\hline $\bar{R}^{2}$ & \multicolumn{2}{|c|}{0.9686} & \multicolumn{2}{|c|}{0.9687} & \multicolumn{2}{|c|}{0.9688} & \multicolumn{2}{|c|}{0.9691} & \multicolumn{2}{|c|}{0.9703} \\
\hline SE & \multicolumn{2}{|c|}{0.2024} & \multicolumn{2}{|c|}{0.2018} & \multicolumn{2}{|c|}{0.2015} & \multicolumn{2}{|c|}{0.2007} & \multicolumn{2}{|c|}{0.1984} \\
\hline
\end{tabular}

NOTE: SE, standard error.

Table 7

Estimates of Equation (1) with SYC and Alternative Supply Measures (January 1985-June 2008)

\begin{tabular}{|c|c|c|c|c|c|c|c|c|c|c|}
\hline Variable & Coefficient & $p$-Value & Coefficient & $p$-Value & Coefficient & $p$-Value & Coefficient & $p$-Value & Coefficient & $p$-Value \\
\hline Const. & -0.4507 & 0.0115 & -0.5291 & 0.0013 & -0.8071 & 0.0531 & -0.5240 & 0.3026 & 0.1946 & 0.1944 \\
\hline gap & 0.1708 & 0.0021 & 0.2173 & 0.0002 & 0.1289 & 0.0013 & 0.0998 & 0.0119 & 0.1105 & 0.0049 \\
\hline cpi & 0.0257 & 0.1834 & 0.0189 & 0.2795 & 0.0482 & 0.0124 & 0.0568 & 0.0414 & 0.0282 & 0.1149 \\
\hline Irid & -0.0387 & 0.4037 & -0.0399 & 0.3751 & -0.0709 & 0.0150 & -0.0998 & 0.0005 & -0.1161 & 0.0001 \\
\hline$r v$ & 0.5325 & 0.0001 & 0.5211 & 0.0001 & 0.2856 & 0.0006 & 0.2563 & 0.0006 & 0.2257 & 0.0022 \\
\hline$S Y C_{t-1}$ & 0.8471 & 0.0000 & 0.8177 & 0.0000 & 0.8905 & 0.0000 & 0.9112 & 0.0000 & 0.9075 & 0.0000 \\
\hline$A M$ & 0.0027 & 0.3846 & & & & & & & & \\
\hline$P 10$ & & & 0.0201 & 0.0959 & & & & & & \\
\hline DUR & & & & & 0.1375 & 0.0268 & & & & \\
\hline DUR10 & & & & & & & 0.0705 & 0.2073 & & \\
\hline S2duradj & & & & & & & & & 0.0000 & 0.6032 \\
\hline $\bar{R}^{2}$ & \multicolumn{2}{|c|}{0.9740} & \multicolumn{2}{|c|}{0.9741} & \multicolumn{2}{|c|}{0.9699} & \multicolumn{2}{|c|}{0.9689} & \multicolumn{2}{|c|}{0.9686} \\
\hline SE & \multicolumn{2}{|c|}{0.1948} & \multicolumn{2}{|c|}{0.1940} & \multicolumn{2}{|c|}{0.1980} & \multicolumn{2}{|c|}{0.2014} & \multicolumn{2}{|c|}{0.2023} \\
\hline
\end{tabular}

NOTE: SE, standard error. 
Table 6 presents the estimates using $S 1, S 2, S 3, S 3^{g d p}$, and $S^{G V}$. None of these measures provides support for the portfolio balance channel. The coefficients on $S 1$ and $S 3$ are positive but not statistically significant. The coefficients on $S 2, S 3^{g d p}$, and $S^{G V}$ are negative; however, none is statistically significant at the 5 percent significance level.

Table 7 presents the estimates using the five alternative supply measures. These results are somewhat more supportive of the portfolio balance channel. The coefficient estimates for $A M$ and $P 10$ are positive but not statistically significant at the 5 percent level. The coefficient on $P 10$ is marginally significant at the 10 percent level but is small: A 1-percentage-point increase in the percent of debt with maturity of 10 years or longer increases SYC by only 2 basis points.

The coefficient on DUR is positive and statistically significant. A 1-year increase in DUR would increase the SYC by nearly 14 basis points. However, the standard deviation of DUR over the sample period is about 0.5 years. Consequently, a relatively large change in DUR would be required to have a very large effect on SYC. D'Amico et al. (2012) indicate that the average duration of the Treasury securities held by the public declined from 4.42 years to 4.30 years during the first LSAP. Hence, this would account for only about a 2-basis-point flattening of the yield curve during this period. They note that QE1 removed only 0.10 years of duration from the market, so the duration effect of QE2 would be even smaller.

The duration-adjusted $S 2$ supply measure also provides no support for the portfolio balance channel. The estimated coefficient is positive, but it is also very small and not statistically significant.

Overall, the evidence is more supportive of the portfolio balance effect using SYC. Two of the 10 supply measures yield coefficients that are correctly signed and statistically significant. However, in either case the effect on SYC is modest. Consequently, the measures cannot account for the well-documented decline in long-term interest rates and the term premium reported in the event study literature.

\section{CONCLUSION}

With its principal policy tool-the federal funds rate-effectively at zero, the FOMC has attempted to stimulate aggregate demand by reducing longer-term rates through the so-called signaling and portfolio balance channels of policy. The portfolio balance channel assumes that the market for long-term Treasury securities is segmented from the rest of the financial market and hypothesizes a positive relationship between the term premium in long-term bonds and the quantity of long-term debt held by the public. By implication, the portfolio balance channel suggests that term premiums, and consequently long-term Treasury yields, can be reduced through LSAPs or by purchasing longer-term securities while simultaneously selling an equal quantity of shorter-term securities.

This article uses the reduced-form methodology of Gagnon et al. (2011) and Krishnamurthy and Vissing-Jorgensen (2012) to investigate the portfolio balance channel with 3 interest rate measures and 10 public debt supply measures from the literature. The results indicate there is 
no statistically significant positive relationship between either the term premium or the 10-year Treasury yield and any of the 10 supply measures. However, there is a statistically significant relationship between the SYC and 2 of the 10 supply measures. The estimate of the effect is very small and cannot account for the estimates of the effect of LSAPs on long-term yields reported in the event study literature. Hence, there appears to be no empirical support for the idea that these purchases reduced long-term yields or flattened the yield curve by reducing the public's holdings of long-term debt as the portfolio balance channel suggests it should have. 


\section{Thornton}

\section{NOTES}

1 See Thornton (2010).

2 See Thornton (2013) for an analysis of the extent to which the announcement effects in the event study literature are identified.

3 Specifically, Bernanke notes that "The channels through which the Fed's purchases affect longer-term interest rates and financial conditions more generally have been subject to debate. I see the evidence as most favorable to the view that such purchases work primarily through the so-called portfolio balance channel, which holds that once short-term interest rates have reached zero, the Federal Reserve's purchases of longer-term securities affect financial conditions by changing the quantity and mix of financial assets held by the public."

4 This formulation seems at odds with the concept of scarcity. A more natural measure would seem to be the public's holding of Treasury securities of given maturities relative to the total supply of those maturities.

5 I would like to thank the authors of these studies for providing the data. The data for the article by Hamilton and Wu (2012) can be found at http://research.stlouisfed.org/econ/thornton/.

6 The results are quantitatively similar and the qualitative conclusions identical if the Hamilton and Wu base series is used, suggesting that including or excluding TIPS has only a minor effect on the results.

7 They provide no reason for making this adjustment. They merely note that they made it.

8 The Greenwood and Vayanos measure is available only through December 2007. Hence, estimates of equation (1) using their measure are based on monthly data over the period January 1985 through December 2007.

9 Bauer and Rudebusch (2011) have an alternative estimate of the risk premium. However, their measure behaves similarly to that of Gagnon et al. (2011). Indeed, the qualitative conclusions presented in this section are the same when the Bauer and Rudebusch measure is used.

${ }^{10}$ See Gagnon et al. (2011) for the precise definitions of these variables.

${ }^{11}$ As before, the qualitative conclusions are unchanged if the 10-year Treasury yield or Bauer and Rudebusch's (2011) measure of the term premium is used. For completeness, Hamilton and Wu's (2012) supply factors were also used. These factors are available for the period January 1990 through July 2007. None of these supply factors was statistically significant when either TP or T10 was the dependent variable.

\section{REFERENCES}

Bauer, Michael and Rudebusch, Glenn. "The Signaling Channel for Federal Reserve Bond Purchases." Working Paper No. 2011-21, Federal Reserve Bank of San Francisco, September 2011; http://www.frbsf.org/economic-research/files/wp11-21bk.pdf.

Bernanke, Ben S. "The Economic Outlook and Monetary Policy." Speech at the Federal Reserve Bank of Kansas City Economic Policy Symposium, Jackson Hole, Wyoming, August 27, 2010; http://www.federalreserve.gov/newsevents/speech/bernanke20100827a.htm.

Cochrane, John H. "Sense and Nonsense in the Quantitative Easing Debate." VOX, December 7, 2010; http://www.voxeu.org/index.php?q=node/5900.

Cochrane, John H. "Inside the Black Box: Hamilton, Wu, and QE2." Unpublished manuscript, University of Chicago Booth School of Business, March 3, 2011; http://faculty.chicagobooth.edu/john.cochrane/research/papers/hamiton_wu_term_structure.pdf.

D’Amico, Stefania; English, William B.; Lopez-Salido, J. David and Nelson, Edward. "The Federal Reserve's LargeScale Asset Purchase Programs: Rationale and Effects." Finance and Economics Discussion Series No. 2012-85, Board of Governors of the Federal Reserve System, December 2012; http://www.federalreserve.gov/pubs/feds/2012/201285/201285abs.html. 
D'Amico, Stefania and King, Thomas B. "Flow and Stock Effects of Large-Scale Treasury Purchases." Finance and Economics Discussion Series No. 2010-52, Board of Governors of the Federal Reserve System, September 2010; http://www.federalreserve.gov/pubs/feds/2010/201052/201052abs.html.

Gagnon, Joseph; Raskin, Matthew; Remache, Julie and Sack, Brian. "The Financial Market Effects of the Federal Reserve's Large-Scale Asset Purchases." International Journal of Central Banking, March 2011, 7(1), pp. 3-43.

Greenwood, Robin and Vayanos, Dimitri. "Bond Supply and Excess Bond Returns." Review of Financial Studies (forthcoming). Advance Access published online January 14, 2014;

http://rfs.oxfordjournals.org/content/early/2014/01/14/rfs.hht133.full.pdf+html.

Hamilton, James D. and Wu, Jing Cynthia. "The Effectiveness of Alternative Monetary Policy Tools in a Zero Lower Bound Environment." Journal of Money, Credit, and Banking, February 2012, 44(Suppl. s1), pp. 3-46.

Hancock, Diana and Passmore, Wayne. "Did the Federal Reserve's MBS Purchase Program Lower Mortgage Rates?" Journal of Monetary Economics, July 2011, 58(5), pp. 498-514.

Joyce, Michael; Lasaosa, Ana; Stevens, Ibrahim and Tong, Matthew. "The Financial Market Impact of Quantitative Easing." Working Paper 393, Bank of England, August 2010;

http://www.bankofengland.co.uk/research/Documents/workingpapers/2010/wp393.pdf.

Kim, Don H. and Wright, Jonathan H. "An Arbitrage-Free Three-Factor Term Structure Model and the Recent Behavior of Long-Term Yields and Distant-Horizon Forward Rates." Finance and Economics Discussion Series No. 2005-33, Board of Governors of the Federal Reserve System, August 2005; http://www.federalreserve.gov/pubs/feds/2005/200533/200533pap.pdf.

Kocherlakota, Narayana. "Economic Outlook and the Current Tools of Monetary Policy." Speech at the European Economics and Financial Centre, London, England, September 29, 2010; http://minneapolisfed.org/news_events/pres/speech_display.cfm?id=4555.

Krishnamurthy, Arvind and Vissing-Jorgensen, Annette. "The Effects of Quantitative Easing on Long-Term Interest Rates." Brookings Papers on Economic Activity, Fall 2011, pp. 215-65.

Krishnamurthy, Arvind and Vissing-Jorgensen, Annette. "The Aggregate Demand for Treasury Debt." Journal of Political Economy, April 2012, 120(2), pp. 233-67.

Neely, Christopher J. “Unconventional Monetary Policy Had Large International Effects.” Working Paper No. 2010-018D, Federal Reserve Bank of St. Louis, July 2010, revised August 2013; http://research.stlouisfed.org/wp/2010/2010-018.pdf.

Stroebel, Johannes and Taylor, John B. "Estimated Impact of the Fed's Mortgage-Backed Securities Purchase Program." NBER Working Paper No. 15626, National Bureau of Economic Research, December 2009; http://www.nber.org/papers/w15626.pdf?new_window=1.

Swanson, Eric T. “Let's Twist Again: A High-Frequency Event-Study Analysis of Operation Twist and Its Implications for QE2." Working Paper No. 2011-08, Federal Reserve Bank of San Francisco, February 2011; http://www.frbsf.org/economic-research/files/wp11-08bk.pdf.

Thornton, Daniel L. "Can the FOMC Increase the Funds Rate Without Reducing Reserves?" Federal Reserve Bank of St. Louis Economic Synopses, 2010, No. 28, October 6, 2010; http://research.stlouisfed.org/publications/es/10/ES1028.pdf.

Thornton, Daniel L. "An Evaluation of Event-Study Evidence on the Effectiveness of the FOMC's LSAP Program: The Reasonable Person Standard." Working Paper No. 2013-033A, Federal Reserve Bank of St. Louis, October 2013; http://research.stlouisfed.org/wp/2013/2013-033.pdf.

Vayanos, Dimitri and Vila, Jean-Luc. "A Preferred-Habitat Model of the Term Structure of Interest Rates." NBER Working Paper No. 15487, National Bureau of Economic Research, November 2009; http://www.nber.org/papers/w15487.pdf?new_window=1.

Woodford, Michael. "Monetary Policy in the Information Economy," in Economic Policy for the Information Economy. Proceedings of the Economic Policy Symposium sponsored by the Federal Reserve Bank of Kansas City, Jackson Hole, Wyoming, August 20-September 1, 2001, pp. 297-370; http://www.kansascityfed.org/Publicat/sympos/2001/papers/S02wood.pdf. 


\section{Thornton}

Woodford, Michael. "Methods of Policy Accommodation at the Interest-Rate Lower Bound," in The Changing Policy Landscape. Proceedings of the Economic Policy Symposium sponsored by the Federal Reserve Bank of Kansas City, Jackson Hole, Wyoming, August 20-September 1, 2012, pp. 185-288; http://www.kansascityfed.org/publicat/sympos/2012/Woodford_final.pdf.

Wright, Jonathan H. "What Does Monetary Policy Do to Long-Term Interest Rates at the Zero Lower Bound?" Economic Journal, November 2012, 122(564), pp. F447-66. 